Studia Ceranea 1, 2011, p. 191-204

Anna-Maria Totomanova (Sofia)

\title{
A Lost Byzantine Chronicle in Slavic Translation
}

A couple of years ago I started working on an understudied chronographic text identified as the Slavic Version of the Chronicle of George Synkellos. The work was introduced to the Slavic studies community thanks to the copy in the collection of V. M. Undolsky. In the manuscript it follows on immediately after the Chronicle of Hamartolos in its second redaction ${ }^{1}$. The similarity between this unknown to the scholarship of the time text and the Chronicle of George Synkellos was noted yet by Undolsky himself. V.M. Istrin contributed to the final identification of the text as a Slavic version of the Chronicle of George Synkellos. The scholar believed that the Slavic text contains an abridged redaction of the chronicle although nothing similar was found in the Greek copies of Synkellos' work he was familiar with ${ }^{2}$. Istrin reached the conclusion that the chronicle's translation appeared in Kievan Rus in the $14^{\text {th }}$ century on the grounds of some cursory observations on the copy's language. The text has been preserved in five Russian copies of the $15^{\text {th }}$ or the $16^{\text {th }}$ centuries, manifesting no textological differences ${ }^{3}$.

\footnotetext{
1 Х. ТрендАфилов, Наблюдения върху славянския превод на хрониката на Георги Синкел, PBg 14.4, 1990, p. 102.

2 В.М. Истрин, Из области древне-русской литературы, ЖМНП 1903, август, р. 401:

3 Until the mid-1980s we were familiar with only four copies of this work: two from Moscow, kept in the Russian State Library (Undolskiy [cetera: Унд.] № 1289 of Moscow (III +488 f.), 1, f. 405-488b and Egorov № $9081^{\circ}$, (I+ 615 f.) f. 497-615.) and two Petersburg's copies, kept in the National Library of Russia (Sofijski [cetera: Coф.] № 1474, II+397 ff. 4º f. 34-135a and Solovecki [cetera: Сол.] № 829/839, $4^{\circ}, 656$ f.; f. 2-221a). The first two date to the $15^{\text {th }}$ century and the second two - to the $16^{\text {th }}$ century (Х. ТрендАФиЛов, ор. cit., p. 102; О.В. Творогов, Хроника Георгия Синкелла в Древней Руси, [in:] Исследования по древней и новой литературе, Ленинград 1987, p. 217. Traditionally the copy of Undolskiy was believed to be the earliest and it lies in the basis of our edition too (cf. A.-М. Тотоманова, Славянската версия на хрониката на Георги Синкел. Издание и коментар, София 2008). Recently however another copy of the chronicle from Egorov's collection was introduced into science (Egorov 863), which has a dating (a marginal note of 1452) and is relatively earlier (Т.В. АнисимовА, Хроника Георгия Амартола в древнерусских списках XIV-XV вв., Москва 2009, p. 89-93). Textologically Egorov 863 does not differ from the other Moscow copies of which only the Undolsky manifests petite deviations mainly expressed in omissions, word shuffles and lexical changes (Н.В. БРАЖниковА, Из наблюдений над списками славянского перевода Хроники Георгия Синкелла, [in:] Лингвистическое
} 
For decades now, the interest in this understudied Slavic chronicle has been more than sporadic and no researcher questioned Istrin's opinion that this was an abridged and probably draft version of Synkellos. To a great extent this was due to the limited text material adduced by Istrin ${ }^{4}$, and for want of serious research and an edition of the work. As a matter of fact, most Slavic chronographic heritage researchers (M. Weingart, A. Meshterskiy, O. Tvorogov, M.D. Priselkov) merely repeat Istrin's hypothesis on the origin and the contents of the chronicle ${ }^{5}$. As regards the place and the time of the translation, however, the researchers are not that unanimous. M. Priselkov, like Istrin, bound the translation of the Synkellos' chronicle with the translation of Hamartolos. Unlike Istrin, however, he believes that the translation appeared in a much earlier age ${ }^{6}$ and that it should be referred to the translation endeavors of Yaroslav in the 1040s in Kiev. Bulgarian scholar Y. Trifonov was the first ${ }^{7}$ to suggest that judging by the chronicle's linguistic characteristics and by the information it contains, it was more likely to have been translated in Bulgaria in the tenth or eleventh centuries. Some 60 years later another Bulgarian scholar, Ch. Trendafilov, drew the attention to the fact that the historical account is situated between two chronological poles: the Creation of the world and the foundation of Constantinople - and features episodes from the Old-Testament and from the Roman history as well as from the histories of other nations. Thus where both the chronicle's scope and the selection of the episodes suggest an ideological purpose, meant to prepare the society for adopting Christian history ${ }^{8}$. This, which again leads us to the Bulgarian reality of the tenth and eleventh centuries. In support of his thesis Trendafilov quotes a number of lexemes of indisputable Bulgarian origin.

In my brief presentation I will try to share and illustrate my main conclusions on the publication and the research of the text. The Slavic chronicle proved to be a chronographic compilation about the events from the Creation of the world to the

источниковедение и история русского языка, Москва 2000, p. 106-118). The first notice of this translation see in: Предварительный список славяно-русских рукописных книг XV в., хранящиихся в СССР (Для сводного каталога рукописных книг хранящихся в СССР), сост. А. Турилов, Москва 1986, p. 100.

4 This fact was also noted by Х. ТренДАфИЛов, op. cit., p. 101.

5 Cf. M. Weingart, Byzantské kroniky v literatuře církevněslovanské. Přehled a rozbor filologický, v Bratislavě, pars 1, 1922, p. 52-55; Н.А. МещЕРскИй, Источники и состав древней славянорусской письменности IX-XV вв., Ленинград 1978, p. 85-87; О.В. Творогов, Древнерусские хронографбы, Ленинград 1975, p. 9; IDEм, Хроника Георгия Синкелла...; М.Д. ПриСелков, История русского летописания XI-XV вв., Санкт-Петербург, 1996, p. 65. Detailed review of the history of research of the Slavic text see in: Х. ТрендАфилов, op. cit., p. 101-102.

6 М. Д. ПриСЕЛКОВ, оp. cit., p. 65.

7 Ю. Трифонов, Византийските хроники въ иғрковнославянската книжнина, ИИД 6,1924, p. $169-170$.

8 Х. ТреНДАФИЛОВ, op. cit., p. 104. 
founding of Constantinople, rather than an abridged version of the Chronicle of George Synkellos.

The first part, encompassing about two-thirds of the work's size (405a1 - 458b15 in Und. 1289), contains an excerpt from the Chronicle of Julius Africanus about the years from the Creation of the world to the Resurrection of Christ. The identification of Africanus as the author of this part of the chronographic compilation was made on the basis of different types of evidence, which could be summarized as follows:

The narrative in this part is completely based on the chronological and the Christological concept of Africanus, who interprets the world history from the Creation to the Resurrection as a fulfillment of God's providence in six days (millennia). This chronological treatment of world history differs from the Synkellos' concept presented in the second part of the work.

a. The story until Christ's birth, which encompasses Old-Testament history and part of the history of ancient Rome, Persia and the Hellenistic world, is built on 23 chronological observations, each containing Africanus' dates and calculations, where part of the chronologies agree with some preserved fragments of Africanus?. The chronological observations form the backbone of the account in the first part and manifest a frequency much higher than that of the chronologies in the second part (see Table 1).

Table 1

\begin{tabular}{|c|c|c|}
\hline 1. & $\begin{array}{l}\text { 406a18-20 Chronology from Adam to } \\
\text { Enos }\end{array}$ & year 435 \\
\hline 2. & 406b24-25 Chronology of the Flood & 2262 \\
\hline 3. & $\begin{array}{l}\text { 407b1-6 Chronology of the migration of } \\
\text { Abraham }\end{array}$ & $\begin{array}{l}3277 \text { Abraham was } 75 \text {-years old } \\
\text { When he was } 100 \text { his son Isaac was born } \\
\text { Isaac is } 60 \text { - Jacob/Israel } \\
\text { Jacob/Israel entered Egypt at the age of } \\
130 \\
\text { A total of } 215 \text { years until Jacob's entry in } \\
\text { Egypt } \\
\text { Jacob died in Egypt and after } 70 \text { years } \\
\text { Joseph died }\end{array}$ \\
\hline 4. & $\begin{array}{l}\text { 411a6-14 Chronology of the death of } \\
\text { Joseph }\end{array}$ & 3563 \\
\hline
\end{tabular}

9 The fragments were identified after the edition of Routh (Julii Africani Emmauntis, seu Nicopolis, apud Palaestinam episcopi, qui post initia saeculi tertii scripsit, reliquiae, ed. M.J. Routh, [in:] Reliquae Sacrae, vol. II. Oxford 1846, p. 225-309), because the new edition of the fragments of Africanus was published only months prior to my book. 


\begin{tabular}{|c|c|c|}
\hline 5 . & $\begin{array}{l}\text { 412b21-413a16 Chronology of the } \\
\text { Exodus and the } 430 \text { years of exile }\end{array}$ & $\begin{array}{l}3707 \\
\text { Moses was } 80\end{array}$ \\
\hline 6. & $\begin{array}{l}416 \mathrm{~b} 5-8 \text { Chronology of the death of } \\
\text { Moses }\end{array}$ & 3747 The Exodus lasted 40 years \\
\hline 7. & $\begin{array}{l}417 \mathrm{~b} 20-23 \text { Chronology of the death of } \\
\text { Joshua of Nun }\end{array}$ & $\begin{array}{l}3772 \\
\text { Joshua of Nun - } 25 \text { years }\end{array}$ \\
\hline 8. & $\begin{array}{l}420 \mathrm{~b} 12-18 \text { Chronology of the years of } \\
\text { the judges }\end{array}$ & $\begin{array}{l}4292 \\
490 \text { judges and } 30 \text { old men }\end{array}$ \\
\hline 9. & $\begin{array}{l}\text { 421a7-11 Chronology of Eli, Samuel and } \\
\text { Saul }\end{array}$ & 90 (20 for Eli and 70 for Saul and Samuel) \\
\hline 10. & $\begin{array}{l}\text { 423b8-16 Chronology of the years of } \\
\text { Saul }\end{array}$ & 20 together with Samuel \\
\hline 11. & $\begin{array}{l}428 \mathrm{a} 5-7 \text { Chronology of the separation } \\
\text { of the } 10 \text { tribes and the beginning of the } \\
\text { Samaritan Kingdom }\end{array}$ & 4468 \\
\hline 12. & $\begin{array}{l}\text { 435a11-15 Chronology of the end of the } \\
\text { Samaritan Kingdom }\end{array}$ & 4750 lasted 283 years \\
\hline 13. & $\begin{array}{l}437 \mathrm{~b} 25-438 \mathrm{a} 7 \text { Chronology of the end } \\
\text { of the Kingdom of Judah and the begin- } \\
\text { ning of the Babylonian captivity }\end{array}$ & $\begin{array}{l}4872 \\
122 \text { years after the end of the Samaritan } \\
\text { Kingdom }\end{array}$ \\
\hline 14. & $\begin{array}{l}440 \mathrm{a} 26-440 \mathrm{~b} 3 \text { Chronology of the end of } \\
\text { the Babylonian captivity }\end{array}$ & $\begin{array}{l}4942 \\
70 \text { years of captivity }\end{array}$ \\
\hline 15. & $\begin{array}{l}440 \mathrm{~b} 21-441 \mathrm{a} 2 \text { Chronology of the resto- } \\
\text { ration of the temple }\end{array}$ & 46 years \\
\hline 16. & $\begin{array}{l}\text { 441a2-6 Chronology of Cyrus and the } \\
\text { Persian Kingdom }\end{array}$ & $\begin{array}{l}\text { 4942 } \\
\text { 55. } 1^{\text {st }} \text { Olympiad }\end{array}$ \\
\hline 17. & $\begin{array}{l}442 \mathrm{a} 15-18 \text { Chronology of the Regal pe- } \\
\text { riod in Rome }\end{array}$ & $\begin{array}{l}5000 \\
69 \text { Olympiad }\end{array}$ \\
\hline 18. & $\begin{array}{l}\text { 443b10-19 Chronology of the end of the } \\
\text { Persian Kingdom }\end{array}$ & $\begin{array}{l}5172 \\
230 \text { years }\end{array}$ \\
\hline 19. & $\begin{array}{l}\text { 443b19-444a7 Chronology of the } \\
\text { Macedonian Kingdom and Antioch }\end{array}$ & $\begin{array}{l}+282=5454 \text { to emperor Caesar } \\
+300=5472 \text { to the death of Cleopatra } \\
+264=5436 \text { to the capturing of Antioch } \\
151 \text { Olympiad - beginning of the } \\
\text { Maccabees }\end{array}$ \\
\hline 20. & $\begin{array}{l}448 \mathrm{~b} 27-449 \mathrm{a} 10 \text { Chronology of the years } \\
\text { of the Maccabees }\end{array}$ & $\begin{array}{l}5375 \\
\text { Death of Symon } \\
163 \text { Olympiad }\end{array}$ \\
\hline
\end{tabular}




\begin{tabular}{|l|l|l|}
\hline 21. & $\begin{array}{l}\text { 452b25-453a2 Chronology of the be- } \\
\text { ginning of the Empire in Rome and the } \\
\text { Antiochian chronology }\end{array}$ & $\begin{array}{l}5454 \\
183.2\end{array}$ \\
\hline 22. & $\begin{array}{l}\text { 457a2-9 Chronology of the beginning of } \\
\text { Daniel's prophecy }\end{array}$ & $\begin{array}{l}4942+115=5057 \\
83.3\end{array}$ \\
\hline 23. & $\begin{array}{l}\text { 457b25-458b15 Generalizing chronol- } \\
\text { ogy from the Creation of the world to } \\
\text { the resurrection }\end{array}$ & $\begin{array}{l}5531 \text { Resurrection of Christ } \\
202.2\end{array}$ \\
\hline
\end{tabular}

b. All dates in the first part of the Chronicle follow the chronology of Africanus too. An exception is the date of the Universal flood, which was corrected later, but this correction is mechanical and not in line with the rest of the calculations made in relation to it.

Table 2

\begin{tabular}{|c|c|c|c|}
\hline \multirow{6}{*}{ ПрЖНндьнАА АТТА } & OT'Қ АДАAHA AO ENOCA & \multicolumn{2}{|l|}{435} \\
\hline & потоп々 & \multicolumn{2}{|c|}{2262} \\
\hline & ОБ'ТТ"Қ АВ & \multicolumn{2}{|c|}{3277} \\
\hline & с'ҚАرьт'Қ носн ФОБА & \multicolumn{2}{|c|}{3563} \\
\hline & HcX和' & \multicolumn{2}{|c|}{3707} \\
\hline & 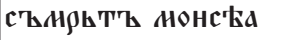 & \multicolumn{2}{|c|}{3747} \\
\hline \multirow{11}{*}{ ВОЕВОАДАНН } & с'Қнрьт'Қ ннсоүса & \multicolumn{2}{|c|}{3772} \\
\hline & стальцн & \multicolumn{2}{|l|}{+30} \\
\hline & с $\mathrm{XAAHA}_{\mathrm{A}}$ & 420 & \multirow{3}{*}{4292} \\
\hline & 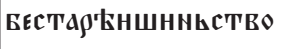 & 40 & \\
\hline & нно' & 30 & \\
\hline & HESEH H $\mathfrak{C} X_{A} A H A$ & 90 & 4382 \\
\hline & ц९ьсттвнга & 490 & 4872 \\
\hline & ПАТА'Қ & 70 & 4942 \\
\hline & ПОЬСКОЕ ЦЦ९СТВО & 230 & 5172 \\
\hline & НАКЕАОНН & 300 & 5472 \\
\hline & ВЪСКЛЬСЕNHE & +59 & 5531 \\
\hline
\end{tabular}


c. Apart from this main chronological scheme of the first part there is another chronological axis introducing Olympiad dating. The year of the first Olympiad coincides with the first year of the reign of Achaz, which is in line with Africanus' chronological concept.

d. The chronological interpretation of Daniel's prophecy about the seventy weeks follows Africanus too as the difference between the 475 solar years since the beginning of the prophecy (at the time of Nehemiah, i.e. the $20^{\text {th }}$ year of Artaxerxes) to the Resurrection and the 490 years of the prophecy is explained with the difference between the solar and the lunar calendars.

To the chronography of Africanus' point the descriptions of the separate periods of universal history to the Resurrection as well:

a. The list of the judges of Israel and the duration of their government (490 years) also belongs to Africanus.

According to our version the list looks as follows:

Chousarsathom 8

Gothoniel 40

Aod $\quad 80$

Aiglom 18

Jabez 20

Deborah 40

Madineans 7

Gideon/Hierobaal 40

Abimelech 3

Moabites 18

Thola $22(23)$

(Jair)

Jephtae 6

Esebon 7

Elon (Malaon) $\quad 10$

Abdon 20

Gentiles 40

Samson 20

Semegar 1

If we sum up the years of their terms minus the years of Jair, who is missing in our text, we will obtain exactly 400 years that together with the forty years of anarchy and the following thirty peaceful years gives 470 . Since Africanus is explicit that the years of the judges, the anarchy and the peace are 490 , the missing Jair must have been judging for 20 years, as Synkellos says. If the years of Thola are 23 as we've assumed, 
it would leave only 19 years to Jair. This list of judges differs from the Synkellos' list but agrees with the supposedly Africanus' list, adduced by Gelzer and restored on the basis of the evidence of medieval chronographs ${ }^{10}$. It can shed additional light on the original text of Africanus.

b. The list of the kings of Judah and Israel and the periods of their reign also follow Africanus.

\section{Kings of Judah:}

Rhoboam

Abia

Asa

Josaphat

Joram

Ochozias

Gotholia 8

Joas 40

Amesias 29

Ozias $\quad 72$

Joatham 16

Achaz 16

\begin{tabular}{lr} 
Ezekias & 8 \\
\hline Total & $\mathbf{2 8 3}$
\end{tabular}

\section{Kings of Israel:}

Jeroboam

Nadab

Baasha

Elah

Zambri 7 days

Ambri

Achaab

Ochozias

Joram

Jeou

Joavhaz

Joas

Jeroboam II

41

Zacharias

9 months

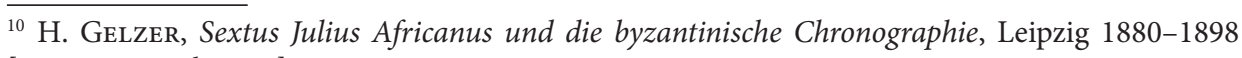
[repr. New York 1997], I, p. 90. 
Saloum

Manaem

Phakesias (Phakee)

Phakee

Osee
1 month

10

2

20

9

The total is 267 years, 10 months and seven days minus the years of Nadav, which are missing in our text but most Byzantine chroniclers give him 2 years ${ }^{11}$. If we assume this figure to be true we will obtain some 270 years for the Israelite kings. The difference between this result and the 283 years until the fall of the Kingdom of Israel should be attributed to the fact that between the reign of Jeroboam II and Zacharias and between that of Phakee and Osee there have been periods of interregna, which are not recorded in our chronicle ${ }^{12}$.

c. The list of Persian kings and the duration of their reign (230 years). Here typical of Africanus is the identification of Cambyses with Nebuchadnezzar II.

Cyrus

31

Cambyses

9

Two brothers magoi $\quad 7$ months

Artabanus

7 months

Darius the Great

36

Xerxes

20

Artaxerxes Longimanus

41

Xerxes II

2 months

Sogdianus

7 months

Darius Notus

19

Xerxes III (Cyrus)

42

Ochus (Artaxerxes)

22

Arses

4

Darius

6

Total

232 y. $11 \mathrm{~m}$.

Exactly 230 years is the sum of the reigns of the rulers, whod reigned for over one year. The order of the Persian kings agrees with that of Africanus restored by Gelzer, with only one discrepancy in the years of Cyrus and Cambysus - respectively

${ }^{11}$ H. Gelzer, op. cit., I, p. 99.

${ }^{12}$ Иллюстрированная полная популярная библейская энииклопедия, еd. архимандрит Никифор, Москва 1891, p. 291. The periods of interregnum are defined 12 and 8 or 9 years respectively, which does not agree with our text. 
30 and 8 years according to his sources ${ }^{13}$. The chronology of Persian kingdom quoted here is in line with Africanus' concept that the $115^{\text {th }}$ year of the Persian reign coincided with the $20^{\text {th }}$ year of the reign of Artaxerxes I, when he allowed for the restoration of Jerusalem (452a2-9) if we count only the years of the kings who've ruled for over one year $(31+9+36+20+20)$.

d. The list of Macedonian rulers - from Alexander the Great to Cleopatra and the duration of their reign (300 years) also agree with Africanus' formulations.

The list of the rulers of the Ptolemaic dynasty and their years according to our chronicle looks as follows:

$\begin{array}{lrr}\text { Ptolemy Lagus } & 114 & (40) \\ \text { Ptolemy Philadelphus } & 124 & 37 \\ \text { Ptolemy Euergetes } & 133 & 25 \\ \text { Ptolemy Philopator } & 139 & 17 \\ \text { Ptolemy Epiphanes } & 143 & 24 \\ \text { Ptolemy Philometor } & 149 & 11 \\ \text { Ptolemy Euergetes Physcon } & 152 & 23 \\ \text { Ptolemy Philopator II } & 158 & \\ \text { Ptolemy Euergetes Physcon } & 158 & 27 \\ \text { Ptolemy Euergetes Physcon } & 164 & 4 \\ \text { Ptolemy Lathyrus } & 165 & 16 \\ \text { Ptolemy Alexander I } & 169 & \\ \text { Ptolemy Alexander II } & 173 & 15 \text { days } \\ \text { Ptolemy Lathyrus } & 173 & 3 \\ \text { Ptolemy Neos Dionysos } & 174 & 25 \\ \text { Cleopatra } & 182 & 22\end{array}$

e. The list of the Seleucids also belongs to Africanus.

According to our chronicle the order of the Seleucid rulers is as follows:

Seleucus

Antoichus Soter

Antiochus Theos

Seleucus Keraunos

Antiochus the Great

Seleucus Philopator

Antiochus Epiphsnes
114

124

129

(138)

139

148

151
$32(33)$

19

15

4

36

12

12

\footnotetext{
${ }^{13}$ H. Gelzer, op. cit., I, p. 103-104.
} 
Antiochus Eupator

Demetrius Soter

Alexander Balas

Demetrius II Nicator

Diodotus Thryphon

Antiochus Sidetes

Demetrius II Nicator

Alexander Zabinas

Antiochus Grypus

Antiochus Cyzicenus

Seleucus

Civil war

Tigranes of Armenia

Antiochus Dionysos

Syria captured by Rome
154

157

159

161

161

163

167

171

171

172

177

177

179
11

9

\section{6}

2

7

14

3

14

f. The list of the seven legendary kings of Rome and the duration of their reign (240 years) also refers to the chronography of Africanus.

Romulus

$38 \quad 6^{\text {th }}$ Olympiad

Numa

$4216^{\text {th }}$ Olympiad

(Tullus Hostilius

$3326^{\text {th }}$ Olympiad)

Ancus Marcius

$23 \quad 34^{\text {th }}$ Olympiad

Tarquinius Priscus

$36 \quad 42^{\text {nd }}$ Olympiad

Servius Tullius

$4450^{\text {th }}$ Olympiad

Tarquinius Superbus

Total

$24 \quad 61 \stackrel{\text { st }}{2}$ Olympiad

g. The description of the miraculous events accompanying Christ's death and Resurrection agrees with one of the most famous fragments of Africanus.

3. Our chronicle contains some important biblical narrative episodes missing altogether in Synkellos' chronicle:

a. The history from the Creation to the Flood.

b. The whole story based on the Book of Ruth with the genealogy of David, the whole account on Samuel, Saul and David after Kings.

c. Part of the story about Solomon.

d. Part of the story about Samson.

e. Part of the story about Jacob and Joseph.

4. The existing agreements between the first part of the chronicle and the Synkellos' text are due to the shared topics and sources: 
a. We find complete conformity between the two sources when the text of Synkellos presents an excerpt from Africanus and partial when the former quotes a shared source, most often the works of Joseph Flavius.

b. In several cases (especially after the introduction of the additional Olympiad dating) our text does not correspond to the Synkellos' version but to that of Eusebius of Caesarea (mostly to the chronological canon translated by St. Jerome) and here the connection between the Slavic text and Synkellos' chronicle is more intricate: Eusebius' canon reflects rather correctly the text of Africanus whereas Synkellos often amasses these notices in his rubric $\Sigma \pi \circ p \alpha \dot{\delta} \eta \nu$ where they remain outside the line of his main account.

The second part of the Slavic chronicle - from the Resurrection to the founding of Constantinople - contains excerpts from the Chronicle of Synkellos about the years until the reign of Diocletian (458b15-482b19 in Унд.1289) complemented with a couple of pages from the chronicle of Theophanes the Confessor (482b20-488b20).

The fitting of the two parts of the chronicle together - to the Resurrection and after it - is rather mechanical. The traces of editorial interventions within the Greek milieu are concentrated mainly on the similar presentation of the material in the parts of Synkellos and of Theophanes the Confessor. The only obvious substantial trace of editing is the correction of the date of the Universal flood - the year 2262 according to Africanus and 2242 according to Synkellos - but this was obviously done on the basis of the calculations of the years of the biblical patriarchs in the Septuagint, rather than to unify the two parts and has therefore not affected the chronologies related to the dating of Africanus.

Gelzer thinks that an excerpt from the chronography of Julius Africanus, exempted of its pre-olympic history of all ancient nations except the Judeans, has probably arisen on Greek soil and in the early ninth century has served as a source of a chronographic compilation used by the most eminent Greek chroniclers such as George Hamartolus, Leo Gramaticus and Cedrenus ${ }^{14}$. For the time being we are more inclined to believe that the Slavic chronicle has not been composed on Bulgarian soil but is a translation of the abovementioned hypothetical Byzantine compilation. It could have appeared only after 816 when Theophanes brought to completion his continuation of the chronicle of Synkellos.

The linguistic analysis reveals that the Slavic translation of the chronicle was made in the early Old-Bulgarian period, probably in the early tenth century. The following specific features support this conclusion:

1. The traces of Glagolitic letters show that the Slavic translation was made in a period when the first Slavic alphabet was in active use.

2. The ancient use of the sign for izhitsa (ypsilon) as a sing for a back labial vowel.

${ }^{14}$ H. Gelzer, op. cit., II, p. 297. 
3. Some errors in the segmentation of the Greek text, which are typical of the earliest translations of the bible.

4. Ancient forms of second sigmatic aorist in first conjugation verbs with liquid consonant root, characteristic of the early Russian copies of Old-Bulgarian originals.

5. The adaptation of the borrowed Greek names or names borrowed through the mediation of Greek manifests substantial differences from the picture we see in the classical Old-Bulgarian texts.

6. The ancient and rare lexis featuring some coincidences with the lexis of the works of the classical Old-Bulgarian corpus, the early Russian copies of OldBulgarian originals and with the language of John Exarch.

The main reason for this particular chronographic compilation to be translated so early lies in its ideological purpose. No other text in the early Slavic literature renders in such a synthesized form and at the same time comprehensively the entire Old-Testament history. Such a work was of paramount importance for a neophyte nation that was only beginning to accumulate liturgical books after the arrival of the disciples of Cyril and Methodius to Bulgaria in 886 such a work was of paramount importance. To a great extent the translation of the chronicle was intended to compensate the lack of a complete translation of the biblical books. Moreover, the chronological concept of Africanus, on which the first part of the chronicle - from the Creation to the Resurrection - is based, was obviously introducing some sort of system in the confused chronology of the Byzantines and the Bulgarians. And so the translation was pursuing rather pragmatic goals, which distinguishes it from the translations of encyclopedic works in the Golden Age. At the same time, the chronicle also gave sufficient knowledge about the history of the Hellenistic world and Ancient Rome from the beginning of the Olympiads onward, which was obviously part of the training of the educated Byzantines. With the translation of the chronicle the Bulgarians received a complete history of Christianity from the Creation of the world to the founding of Constantinople, told in an accessible, comprehensible and concise form. The legendary-mythological beginning of the narration is synthesized

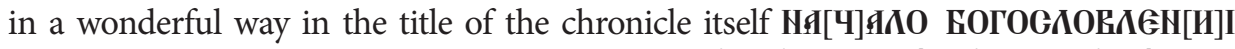

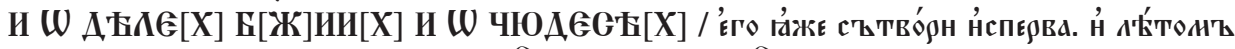

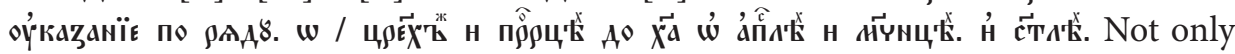
was this chronicle suited for a neophyte nation, which had no written history of their own, but the translation of the text of Africanus fits but naturally in that part of the literary production of the Preslav literary center, which was obviously influenced by the authority of Patriarch Photius and his Bibliotheca containing commentaries on 279 books. Recently the Bulgarian researcher $\mathrm{H}$. Trendafilov listed a total of 12 translated books among which the Hexameron by Basil the Great, translated by John Exarch; the History of the Jewish War by Josephus Flavius; the sermons of 
Chrysostom collected in Simeon's Zlatostrui; the Christian Topography by Cosmas Indicopleust, whose originals were part of or corresponded to analogical works in Photius' Bibliotheca ${ }^{15}$. Photius not only played an active role in the Christianization of Bulgaria, but he was also a spiritual and intellectual tutor and possibly teacher ${ }^{16}$ of the future Bulgarian Tsar Simeon. Therefore it is no accident that the contents of Simeon's Florilegium of 1073 featured works, which had been of interest to Photius himself ${ }^{17}$. The Byzantine patriarch praised highly Africanus' chronography stressing that though concise in his style ",he omits nothing worthy of record” although he described cursorily ( $\dot{\varepsilon} \pi \tau p o \eta \alpha \dot{\alpha} \eta \nu)$ the events from Christ to the reign of Roman Emperor Macrinus ${ }^{18}$. The last maybe explains why the Slavic men of letters did not choose to translate the chronicle of Africanus but opted for the compilation, where the second part described Christianity in much more detail until the summoning of the Council of Nicaea and the founding of Constantinople in the twentieth year of Constantine's the Great reign. Of course, this leaves room for speculation on whether the compilation itself could have been made on Bulgarian soil but until we can undoubtedly rule out the possibility of the existence of an analogical Byzantine compilation this should remain mere guesswork.

It is not accidental that this early Preslav translation (or compilation?) appeared in Russia in the fifteenth century, for this was the time when the Russian imperial idea and the concept of Moscow being the "Third Rome" was formulated; besides, all the extant copies of the chronicle are accompanied by a translation of the chronicle of George Hamartolus, the two Moscow copies (Унд. 1289 and Egorov 908) are placed in the chronographic miscellanies after extensive excerpts of the chronicle of Hamartolus and after the two St. Petersburg’s copies (Соф. № 1474 and Сол. № 829/839) the world history continues following Hamartolus with an account on Constantine the Great. The earliest manuscript Egorov 863 is a borderline case since there the copy of the Chronicle is located after the Chronicle of Hamartolus like in the other two Moscow copies but afterwards the history continues following Hamartolus again with the same rubrics as the Petersburg's copies. The two Petersbourg's cop-

${ }^{15}$ Х. ТреНДАФИЛОВ, Младостта на изар Симеон, София 2010, р. 23-32.

${ }^{16}$ В. ЗлАТАРски, История на българската държава през средните векове. Т. І. Първо българско иарство. 2. От славянизацията на държавата до падането на Първото българско иарство, София 1971, pp. 280-282.

17 П. ЯневА, „Библиотеката” на патриарх Фотий и Симеоновият сборник, [in:] Медиевистичини ракурси. Топос и енигма в кулкурата на православните славяни, София 1993, p. $28-32$.

${ }^{18}$ The exact English translation is as follows: Read the History of Africanus, who was also the author of the Cesti in fourteen books. Although his style is concise, he omits nothing worthy of record. He begins with the Mosaic cosmogony and goes down to the coming of Christ. He also gives a cursory account of events from that time to the reign of Macrinus, at which date, as he tell us, the Chronicle was finished, that is, in the $5723^{\text {rd }}$ year of the world. The work is in five volumes (The Library of Photius, trans. J. H. FreEse, London 1920, p. 34). 
ies' content is more variegated than the Moscow's and features other annalistic, antiheretical and canonical texts.

Within the framework of the research project Concepts of History Across the Slavic Orthodox World the pursuit of Africanus' projections in the historiographic literature of Eastern Europe continues. A translation is under preparation - in Bulgarian and in English - of the part of Africanus to make the text accessible to a wider circle of researchers.

\begin{abstract}
Until recently the so-called Slavic version of the Chronicle of George Synkellos has not been paid proper attention. The attribution of Vasilij Istrin who in the beginning of the $20^{\text {th }} \mathrm{c}$. identified the Slavic text as a translation from an abridged redaction of the Byzantine chronicle, was thoroughly accepted by the Slavic studies researchers. As a result, no great importance was attached to the Slavic text preserved in 5 copies from 15-16 cc. (of which Istrin knew only 4) because of the closed tradition of the copies and their relatively late date. My research linked to the publication of this unedited Slavic chronicle led me to the conclusion that the text referred to as the Slavic version of Synkellos by both Istrin and his successors is not a translation of the Greek Synkellos but rather a chronographic compilation. It was demonstrated that the first part of the compilation narrating the years from the Creation up to the Resurrection of Christ represents a vast excerpt from the Julius Africanus's Christian chronography and only the second part covering the years after the Resurrection up to the foundation of Constantinople contains the respective text of Synkellos plus a couple of pages from the Chronicle of Theophanes the Confessor that was not translated in OCS. Both the discovery of a non fragmented text of Africanus and the conclusion that the Slavic translation was done during the $1^{\text {st }}$ Bulgarian Kingdom in $10^{\text {th }} \mathrm{c}$. raise a series of problems my contribution touches upon.
\end{abstract}

Anna-Maria Totomanova St. Kliment of Ohrid Sofia University 15 Tsar Osvoboditel blvd. 1000 Sofia, Bulgaria atotomanova@abv.bg 